\title{
The Influence of Gender on Omani College Students' English Language Learning Strategies, Comprehension and Motivation
}

\author{
Azhaar Ambu Saidi \\ Sultan Qaboos University
}

Rahma Al-Mahrooqi (corresponding author)

Sultan Qaboos University

E-mail: ralmahrooqi@gmail.com

Received: 08-06- 2012

Accepted: 10-08- 2012

Published: 01-09- 2012

doi:10.7575/ijalel.v.1n.4p.230

URL: http://dx.doi.org/10.7575/ijalel.v.1n.4p.230

\begin{abstract}
Gender's influence on education, especially on foreign language learning, cannot be denied. The current study investigates the effect of gender on English language learning among Omani higher education students. The results indicate that there are differences between males and females with regard to language learning strategies, language comprehension and language learning motivation. Additionally, a relatively large group of participants indicated that gender differences in English language learning cannot be attributed to social and cultural reasons as Omani society provides equal opportunities for both genders to learn English. Most of the study's findings are consistent with previous findings, lending further support to the idea that there are differences between males and females in language learning.
\end{abstract}

Keywords: Gender, learning strategies, comprehension, motivation

\section{Introduction}

Why do medical doctors refuse to give a prescription to any patient unless they know his/her gender? Why do many companies reject CVs that do not include a person's gender? There are good reasons for this. Gender is essential information, as many studies have shown that males and females do not have the same innate abilities. For example, on average, men have been found to be better than women in a subject like mathematics (Kaiser, 2006). But what about learning a second language? Does gender really matter here as it does in other fields? Oxford, Nyikos and Ehrman (as cited in Catalan, 2003) have indicated that "omission of sex as a variable in language learning strategy research is rather surprising, since sex is a classic and significant predictor in other educational, psychological and linguistic research" (p.56).

Gender, then, is considered as one of the main factors that influence second language learning (Andreou, Vlachos \& Andreou, 2005) and ignoring its effect may lead to inappropriate selection of learning environments and materials for both male and female language learners and especially in co-educational institutions. On the other hand, studying the relationship between gender and language learning helps teachers to plan a class accordingly, develop effective strategies (Aslan, 2009), and conduct appropriate in-class activities (Meece, Glienke, \& Burg, 2006).

The influence of gender on learning itself has been a controversial issue for many years. Many researchers have addressed this issue and it is significant, as a basic finding, that Sax (as cited in Kaiser, 2006) has stated that "the fact that each child is unique and complex should not blind us to the fact that gender is one of the two great organizing principles in child development" (p.9).

Different views about why gender differences influence learning have been canvassed. Some point to biological characteristics (Ning, 2010). On the other hand, many reject this relationship, suggesting instead that social and cultural reasons cause the huge gap between men and women in many fields including language learning (Ning, 2010; Kaiser, 2006). 
Many researchers agree, however, that males and females differ when it comes to language learning strategies, comprehension and motivation. Liyanage and Bartlett (2011) have found a difference even in the number and types of language learning strategies used. In addition, Catalan's (2003) claim is in line with Liyanage's and Bartlett's findings, as his results indicate that the number of vocabulary learning strategies used by females differs from that of males. All three researchers, Liyanage, Bartlett and Catalan, agree that in language learning females use a wider range of strategies than males.

In terms of language comprehension, several studies have demonstrated female superiority (Kaiser, 2006). However, some studies show that this varies depending on the type of texts being read. Males tend to comprehend science-oriented passages more easily than females while females achieve a higher level in art-oriented passages (Brantmeier, 2003; Pae, 2004). However, some studies indicate that there are no significant differences at all between males and females in language comprehension (Aslan, 2009).

Beyond language learning strategies and comprehension, males and females also appear to differ in language learning motivation. Studies suggest that males and females differ in general academic motivation and in particular that females are more motivated to learn English than males (Mori \& Gobel, 2006), which might explain their overall superiority in English (Aslan, 2009).

The present study came as a result of the researchers hearing from many students and professors that males and females are not equivalent in terms of their language learning abilities. It seems that studying the relationship between gender and language learning and gender differences in learning English might help teachers to plan learning experiences accordingly and develop strategies to improve students' language acquisition (Aslan, 2009). Because no previous studies focus on the influence of gender among college students in Oman, and as Oman has adopted a co-education system, particularly in institutions of higher education, exploring the differences between males and females in learning English among Sultan Qaboos University students became the main goal of this research.

\section{Review of Literature}

To fully understand the topic, this article includes particular language learning areas in which males and females differ. These include language learning strategies, comprehension, and motivation, and, at the end, it discusses factors to which they may be attributable.

\subsection{Gender differences in language learning strategies.}

What are the techniques that language learners use to improve their language acquisition? And are there differences in terms of the number and type of techniques used by both males and females? Language learning strategies which language learners use consciously (Yilmaz, 2009; Magogwe \& Oliver, 2007) are "any sets of operations, steps, plans, routines used ...to facilitate the obtaining, storage, retrieval, and use of information " (Yilmaz, 2009, p.682).

O'Malley et al. (1985, as cited in Yilmaz, 2010) classify Language learning strategies into three main categories: metacognitive, cognitive and socio-affective, while Oxford (1989, as cited in Aslan, 2009) categorizes them into two classes: direct and indirect. Direct strategies are then sub-classified into memory, cognitive and compensation strategies. Indirect strategies are divided into metacognitive, affective and social strategies (Aslan, 2009). Each category is used for specific language processes in a particular area. Memory strategies are used for language storage and access. And because such strategies link one item or concept in the target language to another, deep understanding is not required for their usage (Aslan, 2009). Grouping and representing sounds in memory are examples of this kind (Yilmaz, 2010). Even though memory strategies are essential, researchers have found that language learners rarely use them. Cognitive strategies, on the other hand, are the "most frequently used" because learners use them to manipulate language (Aslan, 2009). Analyzing, summarizing, and repeating are examples of cognitive strategies (Yilmaz, 2010). When inadequate language knowledge, especially in grammar and vocabulary, causes trouble in comprehension, relevant compensation strategies are again used (Samida, 2004). What's more, learners also use such strategies during speaking and writing, even if they do not have sufficient knowledge (Aslan, 2009). Indirect language strategies, involving metacognitive, affective, and social strategies, are as important as the direct ones although they contribute without direct engagement (Samida, 2004). For example, social strategies are used to communicate with others to develop understanding in the target language and its culture (Aslan, 2009; Yilmaz, 2010), and affective strategies for developing positive feelings and controlling emotional factors (Aslan, 2009; Samida, 2004). Even though all these language learning strategies are differently categorized, they are related to each other (Aslan, 2009). 
There is a strong relationship between the number of language learning strategies used and language proficiency. Research shows that superior language learners use more of them than inferior ones (Magogwe \& Oliver, 2007; Aslan, 2009; Yilmaz, 2010; Wong \& Nunan, 2011), while the best use diverse strategies and combine them (Yilmaz, 2010). Thus, teachers should encourage students to use the above strategies because "Learning is not about cramming in information. It is about looking at issues in various ways and developing capacities, especially the ability to dig below the surface to reach the truth" (Wong \& Nunan, 2011, p.144). Choice will of course depend on age, language purpose, nationality and gender (Aslan, 2009).

Males and females tend to use different types of language learning strategies (Aslan, 2009). While gender is a dominant factor here, mixed conclusions have been reached about it. Ran and Oxford (as cited in Studenska, 2011, p.1351) say that females use memory, cognitive, metacognitive, social and compensation strategies more frequently than males do. Aslan (2009) agrees but he has also found that females use more affective strategies than males. However, some researchers suggest that frequency of affective strategy use is the only aspect in which females are superior to males (Studenska, 2011). Hence, female superiority cannot be generalized as some researchers have concluded that there are no gender differences in this aspect (Studenska, 2011).

\subsection{Gender differences in language comprehension}

Do males and females differ in terms of language comprehension level? "Understanding what other people say or write", says Ylvisaker (2008), varies from one person to another (Brantmeier, 2003) and demands a variety of skills, knowledge, capacities and processes to be fully achieved (Ylvisaker, 2008). Full comprehension means simply to know an utterance, either spoken or written, and to be aware that it has a certain purpose which determines its meaning. But learners must invest much effort to comprehend it. Auditory processing is another necessary skill by which language users understand utterances. Necessary too is recognizing the meaning of words, and their organization, which consists of syntax and morphological knowledge (Ylvisaker, 2008). However, possessing such skills does not necessarily mean that students will understand language completely as its content type and complexity (Brantmeier, 2003), and emotional reaction to the text (Glenberg, 2009) are very important factors in language comprehension.

Whether females and males perform differently in terms of language comprehension is still unclear. Studies have produced different results. Some indicate that there are no significant gender differences (Bacon, 1992; Brantmeier, 2003) while others highlight an opposite view (Payne \& Lynn, 2011). The established differences emphasize merely that gender differences are reasonable to assume. In terms of content, males and females comprehend various kinds of texts differently (Brantmeier, 2003; Pae, 2004). The passages that arouse their interest and curiosity differ. Females are more interested in art-oriented passages, and males are more interested and curious in science-oriented ones (Brantmeier, 2003). Emotional reaction is another factor. Glenberg, (2009) argues that females better understand language that is full of sad and happy feelings, and males in language full of aggression and anger.

If males and females learn differently, this may form obstacles for teachers in mixed classes and they must consider this when conducting tests especially in reading comprehension or listening. Passages selected need to be appropriate for both genders in order to assess them fairly (Brantmeier, 2003; Pae, 2004). As a result, teachers' awareness of gender differences in language learning comprehension is essential for pedagogic success.

\subsection{Gender Differences in Language Learning Motivation}

Naturally a language learner does not take any action without a motive. Self-efficacy beliefs, known as a " [person's] judgment of his/her capabilities to organize and execute courses of action required to attain designated types of performance" (Magogwe \& Oliver, 2007, p.), or as a person's confidence in his/her abilities enables him/her to perform well and succeed in any academic activities (Meece, Glienke \& Burg, 2007; Yusuf, 2011). But does self-efficacy also influence achievement? A strong relationship is found between these two variables and so, as long as students have a high degree of self-efficacy, the more opportunities they have for high academic achievement. While achievement and language acquisition or learning are not synonymous, a motivated learner with self-efficacy is more likely to work hard in learning a language. According to Magogwe and Oliver (2007), students with high self-efficacy work as hard as possible to attain their goals and have high self-esteem and strong eagerness; so they do not give up easily when they face challenges. Based on this, self-efficacy is considered necessary for any foreign language learners. Also language learners with high self-efficacy tend to improve their skills using numerous strategies and, more importantly, they work on their language autonomously (Chan, Spratt, \& Gillian, 2010), meaning that they have the "ability to take charge of

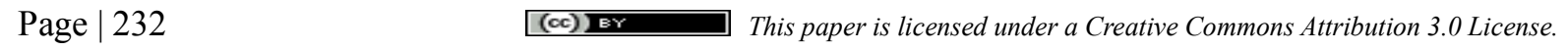


one's own learning" (Varol \& Yilmaz, 2010, p.238). Learners may practice different autonomous activities such as watching programs in English, sending e-mails, reading English newspapers and magazines, listening to English songs, writing notes and recording daily events using English and speaking with native speakers (Chan, Spratt, \& Gillian, 2010). The more strategies and autonomous activities learners use, the higher their language proficiency will be; therefore, developing self-efficacy and instilling a culture of autonomous learning is essential.

Self-efficacy varies from one language learner to another and, more interestingly, its variation depends on gender, among other factors (Choi, 2004). However, this finding cannot be generalized as some researchers have found that there are no significant differences between males and females in term of self-efficacy (Meece, Glienke, \& Burg, 2007). And Varol and Yilmaz (2010) have found no noticeable differences in terms of autonomous language learning between males and females.

However, self-efficacy is a main factor as learners with high self-efficacy are more motivated to improve their language inside and outside the classroom. Moreover, they not depend only on activities provided by their teachers, but work autonomously which is essential for high achievement in language. Thus, developing self-efficacy in both males and females is recommended.

\subsection{Causes of Male and Female Differences in English Language Learning}

None of us can escape from the influence of our society or neglect its role in formulating our characteristics as a person in general and as a language learner. Hence, gender differences in English language learning also exist as a result of the environment around the learners. Even the definition of gender emphasizes the role of society. FAO defines gender as "the relations between men and women, both perceptual and material. Gender is not determined biologically, as a result of sexual characteristics of either women or men, but is constructed socially" (as cited in Ning, 2010, p.126). Hence, gender consists of the traits and manners expected from men and women by society (Ning, 2010).

In Omani society, males and females have different responsibilities and duties, and societal expectations of females are sometimes higher than those of males (Al-Mahrooqi \& Sultana, forthcoming). For example, female students are often expected to do more in their family homes, and are not encouraged to go out of the house much. Hence, female students feel more responsible and less distracted in their studies. In addition, higher education institutions require higher percentages from females for admission. As a result, their doing better than males in the acquisition of English, especially in terms of using language learning strategies (Liyanage \& Bartlett, 2011; Catalan, 2003; Yilmaz, 2010; Aslan, 2009), is not surprising. In addition, as positive expectations affect students' performance and achievement (Gleason, 2002), Omani society's higher expectations of females causes them to work harder to satisfy those around them.

Emotional status also affects English language learning as it influences comprehension. As females tend to be more sensitive, they have, as mentioned already, the capacity to comprehend text or speech full of sadness and happiness more than males, while males better understand context full of aggressiveness and anger (Glenberg, 2009). Furthermore, the degree of fear from and nervousness about negative outcomes varies in both genders as females tend to experience more feeling than males (Rachel \& Uri, 2009). As a result, the superiority of females in using language learning strategies is reasonable as they work as hard as possible to overcome such fears.

In brief, gender a main factor influencing English language learning as males and females differ in such aspects as language learning strategies and comprehension. Moreover, they are not equal in terms of motivation which, as a result, influences their autonomous learning. Consequently, English teachers, especially in co-education systems, must consider gender differences when selecting appropriate teaching strategies and methods.

While the current study follows previous ones in its focus on gender differences in language learning strategies, language comprehension and language learning motivation, it is unique in focusing on Omani students at Sultan Qaboos University. The participants are Arab Muslims and so their cultural framework differs from the most previous studies' participants. It would be insightful to compare Omani male and female strategies, comprehension and motivation on the one hand and to see if results would be similar or different from those of previous studies.

\section{Method}

This chapter introduces the instrument used for collecting data and the participants in the study. Then, it includes a data analysis and discussion section in which the main results are explained and linked to previous research 
findings. After that the main findings are summarized, namely, the ones that are about males and females differences in English language learning. Finally, the paper ends with a concluding section in which readers are reminded of the main findings discovered and the researcher states her recommendations for additional research.

\subsection{Instrument}

For data collection, a questionnaire was developed, validated and piloted on three students by the researchers with the aim of ascertaining its items' clarity and accuracy. The pilot study led to the deletion of some items and the combination of others. The use of a questionnaire was regarded as practical since it enables a researcher to collect a huge amount of data in a short time. By using it, researchers save time too as analyzing questionnaire data can be managed by using a software program. The questionnaire that was distributed to collect data for the current study consists of three sections. In the first section, general background information, such as the subjects' gender, college, major and year of study at the university was requested.

The second section consisted of 27 items provided on a Likert-scale. These items were divided into three sub-sections: gender differences in language learning strategies, gender differences in English language comprehension, and gender differences in English language learning motivation. The third section included one open-ended question that asked about the role played by society and culture in determining gender differences in English language learning.

\subsection{Participants}

As this study aims to explore the influence of gender on English language learning among Sultan Qaboos University students, the questionnaire used for collecting data was distributed to students from four different colleges at Sultan Qaboos University: the College of Arts and Social Science, the College of Education, the College of Science and the College of Engineering. They were 50\% females (40) and 50\% males (40), ranging in years of study at the university from 1-6. Participation in the study was voluntary, and the choice of colleges was random.

\subsection{Data collection procedures}

To obtain a large number of participants, two techniques were used to distribute the questionnaire. The questionnaire was distributed electronically to Arts and Education students and the second technique was a snowball sampling as the researcher asked other students from the College of Science and the College of Engineering to give the questionnaire to some students they knew.

\subsection{Data analysis and discussion}

This study generally aims to examine the question: What is the influence of gender on English language learning among Sultan Qaboos University students? and it specifically sought to investigate the following sub-questions:

1- What gender differences are there in language learning strategies?

2- What gender differences are there in language comprehension?

3- What gender differences are there in language learning motivation?

4- What are the roles of society and culture in gender differences?

Hence, data was analyzed by using SPSS and descriptive statistics for each gender. Means, Standard Deviations and percentages were calculated to address the previous questions. The same descriptive statistics were used to answer the open-ended question in the questionnaire.

Table (1) shows that there is a noticeable correlation $(r=.602)$ between gender and language learning strategies of students who participated in this study at Sultan Qaboos University.

Table 1. Directional Measures

\begin{tabular}{lllr}
\hline Nominal by Interval & Eta & gender dependent & Value \\
& & Gender differences in & .60 \\
& language learning strategies: & .15 \\
& Dependent & \\
\hline
\end{tabular}




\section{International Journal of Applied Linguistics \& English Literature}

ISSN 2200-3592 (Print), ISSN 2200-3452 (Online)

Vol. 1 No. 4; September 2012

Gender differences in language learning strategies can be attributed to males' and females' attitudes toward using such strategies to develop their acquisition of language. The statements in Table 2 show the differences between males' and females' attitudes towards language learning strategies. Only 7 out of 40 males believe that their language always develops more when they use various types of language learning strategies while 22 out of 40 females believe this is so. Moreover, $75.1 \%$ of the sample agree (usually and almost always) that their understanding increases when they use language learning strategies, and females tend to agree more than males as $40 \%$ out of $75.1 \%$ represents females' attitudes. Also, males $(15.1 \%)$ agree more than females $(12.5 \%)$ that using various types of language learning strategies is not important in developing their language performance as they think that there is no difference in their performance whether they use one or many types of language learning strategies or not.

Table 2. Differences between males and females' attitudes towards language learning

\begin{tabular}{|c|c|c|c|c|c|c|c|}
\hline & \multicolumn{4}{|c|}{$\begin{array}{l}\text { 1- My language develops more when I use various } \\
\text { types of language leaning strategies. }\end{array}$} & \multirow[t]{2}{*}{$\mathrm{M}$} & \multirow[t]{2}{*}{ SD } \\
\hline & & $\begin{array}{l}\text { almost } \\
\text { always }\end{array}$ & usually & Sometimes & $\begin{array}{l}\text { almost } \\
\text { never }\end{array}$ & & \\
\hline \multirow[t]{4}{*}{ Gender } & \multirow[t]{2}{*}{ Male } & 7 & 23 & 10 & 0 & \multirow[t]{2}{*}{2.92} & \multirow[t]{2}{*}{.65} \\
\hline & & $8.8 \%$ & $28.8 \%$ & $12.5 \%$ & $.0 \%$ & & \\
\hline & \multirow[t]{2}{*}{ Female } & 22 & 10 & 6 & 2 & \multirow[t]{2}{*}{3.30} & \multirow[t]{2}{*}{.91} \\
\hline & & $27.5 \%$ & $12.5 \%$ & $7.5 \%$ & $2.5 \%$ & & \\
\hline & & \multicolumn{4}{|c|}{$\begin{array}{l}\text { 2- I understand what I learn more when I use } \\
\text { language learning strategies. }\end{array}$} & \multirow[t]{2}{*}{$\mathrm{M}$} & \multirow[t]{2}{*}{ SD } \\
\hline & & $\begin{array}{l}\text { almost } \\
\text { always }\end{array}$ & usually & Sometimes & $\begin{array}{l}\text { almost } \\
\text { never }\end{array}$ & & \\
\hline \multirow[t]{4}{*}{ Gender } & Male & 11 & 17 & 12 & 0 & \multirow[t]{2}{*}{2.95} & \multirow[t]{2}{*}{.90} \\
\hline & & $13.8 \%$ & $21.3 \%$ & $15.0 \%$ & $.0 \%$ & & \\
\hline & \multirow[t]{2}{*}{ Female } & 14 & 18 & 7 & 1 & \multirow[t]{2}{*}{3.12} & \multirow[t]{2}{*}{.79} \\
\hline & & $17.5 \%$ & $22.5 \%$ & $8.8 \%$ & $1.3 \%$ & & \\
\hline & & \multicolumn{4}{|c|}{$\begin{array}{l}\text { 3-There is no difference in my performance whether } \\
\text { I use one or many types of language learning } \\
\text { strategies. }\end{array}$} & \multirow[t]{2}{*}{ Mean } & \multirow[t]{2}{*}{$\begin{array}{l}\text { Std. } \\
\text { Deviation }\end{array}$} \\
\hline & & $\begin{array}{l}\text { almost } \\
\text { always }\end{array}$ & usually & Sometimes & $\begin{array}{l}\text { almost } \\
\text { never }\end{array}$ & & \\
\hline \multirow[t]{4}{*}{ Gender } & \multirow[t]{2}{*}{ Male } & 5 & 7 & 18 & 10 & \multirow[t]{2}{*}{2.17} & \multirow[t]{2}{*}{.95} \\
\hline & & $6.3 \%$ & $8.8 \%$ & $22.5 \%$ & $12.5 \%$ & & \\
\hline & \multirow[t]{2}{*}{ Female } & 2 & 8 & 13 & 17 & \multirow[t]{2}{*}{1.87} & \multirow[t]{2}{*}{.91} \\
\hline & & $2.5 \%$ & $10.0 \%$ & $16.3 \%$ & $21.3 \%$ & & \\
\hline
\end{tabular}

Males and females differ in terms of the types and the number of language learning strategies that they use. In Table 2 Statement 1 shows that females tend to use various types of language learning strategies more than males as the mean for females is 2.8250 compared with that of males which is 2.6250 . Females are superior to males in using memory and cognitive strategies as can be seen from the response to the questions, for example, statement 3, which is an example of memory strategy, and 4, and 5, which are examples of cognitive strategies. However, the results indicated from Statement 6, which was "I tend to summarize what I hear/read in English using my own words," show male superiority as the mean of males is 2.5750 , while the mean of females is 2.55 . As a result, it is predictable that the differences between males and females in using cognitive learning strategies may depend on the nature of the exercise itself. In addition, it can be inferred from the result of Statement 7, in which the mean of males is 3.2750 and the mean of females is 3.4250 , that females use social strategies more than males. The high incidence of Omani females in using such strategies is not surprising because their superiority can be attributed to their nature, as they are more sociable than Omani men. Moreover, they tend to speak and express their feelings more than males. Such results correspond with Ran's and Oxford's views (as cited in Studenska, 2011, p.1351) who found that females use memory, cognitive, compensation, metacognitive 


\section{International Journal of Applied Linguistics \& English Literature \\ ISSN 2200-3592 (Print), ISSN 2200-3452 (Online)}

Vol. 1 No. 4; September 2012

and social strategies more frequently than males. However, these results contradict some researchers' views which indicate that there are no gender differences in this aspect (Studenska, 2011).

As females tend to use various types of language learning strategies more than males, it is expected that females use more learning strategies than males as well. In Statement 2, which is "I do not focus on one strategy to develop my language," females responded positively more than males as the mean of females is 2.92 while the mean of males is 2.57. This result is not surprising for Omani females as they have more responsibilities and duties in their society than males, which makes them more hardworking. This results support the view of Liyanage and Bartlett (2011) that males and females differ in the number of language learning strategies used and that females use more strategies than males.

Table 3. Gender differences in language learning strategies

\begin{tabular}{|c|c|c|c|c|c|c|c|}
\hline & \multicolumn{4}{|c|}{$\begin{array}{l}\text { 1-I use various types of language learning strategies to learn } \\
\text { English. }\end{array}$} & \multirow[t]{2}{*}{$\mathrm{M}$} & \multirow[t]{2}{*}{$\mathrm{SD}$} \\
\hline & & $\begin{array}{l}\text { almost } \\
\text { always }\end{array}$ & Usually & Sometimes & almost never & & \\
\hline \multirow[t]{4}{*}{ Gender } & \multirow[t]{2}{*}{ Male } & 7 & 13 & 18 & 2 & \multirow[t]{2}{*}{2.62} & \multirow[t]{2}{*}{.84} \\
\hline & & $8.8 \%$ & $16.3 \%$ & $22.5 \%$ & $2.5 \%$ & & \\
\hline & \multirow[t]{2}{*}{ Female } & 11 & 14 & 12 & 3 & \multirow[t]{2}{*}{2.82} & \multirow[t]{2}{*}{.93} \\
\hline & & $13.8 \%$ & $17.5 \%$ & $15.0 \%$ & $3.8 \%$ & & \\
\hline & & \multicolumn{4}{|c|}{ 2- I do not focus on one strategy to develop my language. } & \multirow[t]{2}{*}{$\mathrm{M}$} & \multirow[t]{2}{*}{ SD } \\
\hline & & $\begin{array}{l}\text { almost } \\
\text { always }\end{array}$ & Usually & Sometimes & almost never & & \\
\hline \multirow[t]{4}{*}{ Gender } & \multirow[t]{2}{*}{ Male } & 7 & 13 & 16 & 4 & \multirow[t]{2}{*}{2.57} & \multirow[t]{2}{*}{.94} \\
\hline & & $8.8 \%$ & $16.3 \%$ & $20.0 \%$ & $5.0 \%$ & & \\
\hline & \multirow[t]{2}{*}{ Female } & 13 & 12 & 14 & 1 & \multirow[t]{2}{*}{2.92} & \multirow[t]{2}{*}{.88} \\
\hline & & $16.3 \%$ & $15.0 \%$ & $17.5 \%$ & $1.3 \%$ & & \\
\hline & & \multicolumn{4}{|c|}{ 3- I group words in order to memorize them. } & \multirow[t]{2}{*}{ M } & \multirow[t]{2}{*}{ SD } \\
\hline & & $\begin{array}{l}\text { almost } \\
\text { always }\end{array}$ & Usually & Sometimes & almost never & & \\
\hline \multirow{4}{*}{ Gender } & \multirow{2}{*}{ Male } & 5 & 10 & 17 & 8 & \multirow[t]{2}{*}{2.3} & \multirow[t]{2}{*}{1.01} \\
\hline & & $6.3 \%$ & $12.5 \%$ & $21.3 \%$ & $10.0 \%$ & & \\
\hline & \multirow[t]{2}{*}{ Female } & 7 & 12 & 14 & 7 & \multirow[t]{2}{*}{2.47} & .98 \\
\hline & & $8.8 \%$ & $15.0 \%$ & $17.5 \%$ & $8.8 \%$ & & \\
\hline & & 4- I repe & ords many & hes to learn th & & $\mathrm{M}$ & $\mathrm{SD}$ \\
\hline & & $\begin{array}{l}\text { almost } \\
\text { always }\end{array}$ & Usually & Sometimes & almost never & & \\
\hline Gender & Male & 9 & 9 & 16 & 6 & 2.52 & .86 \\
\hline & & $11.3 \%$ & $11.3 \%$ & $20.0 \%$ & $7.5 \%$ & & \\
\hline & Female & 11 & 17 & 8 & 4 & 2.87 & .94 \\
\hline & & $13.8 \%$ & $21.3 \%$ & $10.0 \%$ & $5.0 \%$ & & \\
\hline & & 5- I tenc & nalyze wh & $\mathrm{read} /$ hear in & ish. & $\mathrm{M}$ & $\mathrm{SD}$ \\
\hline & & $\begin{array}{l}\text { almost } \\
\text { always }\end{array}$ & Usually & Sometimes & almost never & & \\
\hline Gender & Male & 8 & 18 & 11 & 3 & 2.77 & .87 \\
\hline & & $10.0 \%$ & $22.5 \%$ & $13.8 \%$ & $3.8 \%$ & & \\
\hline & Female & 10 & 14 & 11 & 5 & 2.72 & .98 \\
\hline & & $12.5 \%$ & $17.5 \%$ & $13.8 \%$ & $6.3 \%$ & & \\
\hline & & $\begin{array}{l}\text { 6- I ten } \\
\text { own wo }\end{array}$ & summari & what I hear/r & n English using my & $\mathrm{M}$ & $\mathrm{SD}$ \\
\hline & & $\begin{array}{l}\text { almost } \\
\text { always }\end{array}$ & Usually & Sometimes & almost never & & \\
\hline
\end{tabular}


International Journal of Applied Linguistics \& English Literature

ISSN 2200-3592 (Print), ISSN 2200-3452 (Online)

Vol. 1 No. 4; September 2012

\begin{tabular}{|c|c|c|c|c|c|c|c|}
\hline \multirow[t]{4}{*}{ Gender } & \multirow[t]{2}{*}{ Male } & 7 & 12 & 18 & 3 & \multirow[t]{2}{*}{2.57} & \multirow[t]{2}{*}{.82} \\
\hline & & $8.8 \%$ & $15.0 \%$ & $22.5 \%$ & $3.8 \%$ & & \\
\hline & \multirow[t]{2}{*}{ Female } & 8 & 10 & 18 & 4 & \multirow[t]{2}{*}{2.55} & \multirow[t]{2}{*}{.93} \\
\hline & & $10.0 \%$ & $12.5 \%$ & $22.5 \%$ & $5.0 \%$ & & \\
\hline & & \multicolumn{4}{|c|}{$\begin{array}{l}\text { 7- I like communicating with native speakers to develop my } \\
\text { English. }\end{array}$} & \multirow[t]{2}{*}{$\mathrm{M}$} & \multirow[t]{2}{*}{$\mathrm{SD}$} \\
\hline & & $\begin{array}{l}\text { almost } \\
\text { always }\end{array}$ & Usually & Sometimes & almost never & & \\
\hline \multirow[t]{4}{*}{ Gender } & \multirow[t]{2}{*}{ Male } & 19 & 14 & 6 & 1 & \multirow[t]{2}{*}{3.27} & \multirow[t]{2}{*}{.65} \\
\hline & & $23.8 \%$ & $17.5 \%$ & $7.5 \%$ & $1.3 \%$ & & \\
\hline & \multirow[t]{2}{*}{ Female } & 22 & 15 & 1 & 2 & \multirow[t]{2}{*}{3.42} & \multirow[t]{2}{*}{.78} \\
\hline & & $27.5 \%$ & $18.8 \%$ & $1.3 \%$ & $2.5 \%$ & & \\
\hline
\end{tabular}

As is shown in Table 4, more than half of the female participants responded negatively to the statement, "I hardly understand what others say or write in English," while only 14 male participants responded negatively. This result corresponds with Payne's and Lynn's (2011) view that females and males differ in language comprehension. However, Brantmeier (2003) and (Pae) 2004 have clarified that male and female differences in language comprehension vary depending on the type of texts used. Brantmeier (2003) indicates that females understand more art-oriented passages while males understand more science-oriented passages. Statements 4 and 5 in Table 4 support the previous view as female responses $(M=2.6)$ to Statement 4 indicate that they understand art-oriented passages more than males $(M=2.3250)$. On the other hand, male responses to Statement $5(M=2.55)$ show that males comprehend science-oriented passages more than females $(M=2.025)$. Male and female comprehension may vary also because of emotional reactions as Glenberg (2009) has stated that females interact more with passages that are full of emotion and sensitivity while males interact more with passages that are full of action and fighting. The results of the current study correspond with Glenberg's (2009) view as the mean of males in Statement 4, "I interact more with English texts that contain action and fighting," $(\mathrm{M}=2.55)$ while the mean of females is just $\mathrm{M}=2.32$. However, females responded that they interact more with sensitive and emotional passages $(M=2.70)$, more than males did $(M=2.3250)$ as results in Statement 3 show. These differences between males and females are not surprising as Omani females tend to be more emotional and sensitive since their central responsibility in society, which is taking care of their families and their children, requires such emotions, while Omani males have more aggressive feelings as they are the ones who have to protect their families from danger, a responsibility shared by males around the world.

Table 4. Gender differences in language comprehension

\begin{tabular}{|c|c|c|c|c|c|c|c|}
\hline & \multicolumn{4}{|c|}{$\begin{array}{l}\text { 1- I hardly understand what others say or write in } \\
\text { English. }\end{array}$} & \multirow[t]{2}{*}{$\mathrm{M}$} & \multirow[t]{2}{*}{ SD } \\
\hline & & $\begin{array}{l}\text { almost } \\
\text { always }\end{array}$ & usually & sometimes & almost never & & \\
\hline \multirow[t]{4}{*}{ Gender } & \multirow[t]{2}{*}{ Male } & 6 & 8 & 12 & 14 & \multirow[t]{2}{*}{2.15} & \multirow[t]{2}{*}{1.07} \\
\hline & & $7.5 \%$ & $10.0 \%$ & $15.0 \%$ & $17.5 \%$ & & \\
\hline & \multirow[t]{2}{*}{ Female } & 1 & 2 & 13 & 24 & \multirow[t]{2}{*}{1.50} & \multirow[t]{2}{*}{.72} \\
\hline & & $1.3 \%$ & $2.5 \%$ & $16.3 \%$ & $30.0 \%$ & & \\
\hline & & \multicolumn{4}{|c|}{$\begin{array}{l}\text { 2- I interact more with English texts that are full of } \\
\text { sensitive and emotional feelings. }\end{array}$} & \multirow[t]{2}{*}{$\mathrm{M}$} & \multirow[t]{2}{*}{$\mathrm{SD}$} \\
\hline & & $\begin{array}{l}\text { almost } \\
\text { always }\end{array}$ & usually & sometimes & almost never & & \\
\hline \multirow[t]{4}{*}{ Gender } & Male & 2 & 15 & 17 & 6 & \multirow[t]{2}{*}{2.32} & \multirow[t]{2}{*}{.79} \\
\hline & & $2.5 \%$ & $18.8 \%$ & $21.3 \%$ & $7.5 \%$ & & \\
\hline & \multirow[t]{2}{*}{ Female } & 9 & 13 & 15 & 3 & \multirow[t]{2}{*}{2.70} & \multirow[t]{2}{*}{.91} \\
\hline & & $11.3 \%$ & $16.3 \%$ & $18.8 \%$ & $3.8 \%$ & & \\
\hline & & \multicolumn{4}{|c|}{$\begin{array}{l}\text { 3- I interact more with English texts that contain action } \\
\text { and fighting. }\end{array}$} & $\mathrm{M}$ & $\mathrm{SD}$ \\
\hline
\end{tabular}


International Journal of Applied Linguistics \& English Literature

ISSN 2200-3592 (Print), ISSN 2200-3452 (Online)

Vol. 1 No. 4; September 2012

\begin{tabular}{|c|c|c|c|c|c|c|c|}
\hline & & $\begin{array}{l}\text { almost } \\
\text { always }\end{array}$ & usually & sometimes & almost never & & \\
\hline Gender & Male & 7 & 13 & 15 & 5 & 2.55 & .93 \\
\hline & & $8.8 \%$ & $16.3 \%$ & $18.8 \%$ & $6.3 \%$ & & \\
\hline & Female & 4 & 10 & 21 & 5 & 2.32 & .83 \\
\hline & & $5.0 \%$ & $12.5 \%$ & $26.3 \%$ & $6.3 \%$ & & \\
\hline & & 4- I unc & ind more & oriented En & h passages. & $\mathrm{M}$ & $\mathrm{SD}$ \\
\hline & & $\begin{array}{l}\text { almost } \\
\text { always }\end{array}$ & usually & sometimes & almost never & & \\
\hline Gender & Male & 2 & 14 & 19 & 5 & 2.32 & .76 \\
\hline & & $2.5 \%$ & $17.5 \%$ & $23.8 \%$ & $6.3 \%$ & & \\
\hline & Female & 5 & 15 & 19 & 1 & 2.6000 & .74421 \\
\hline & & $6.3 \%$ & $18.8 \%$ & $23.8 \%$ & $1.3 \%$ & & \\
\hline & & 5- I unc & ind more & ence-oriente & nglish passages. & $\mathrm{M}$ & SD \\
\hline & & $\begin{array}{l}\text { almost } \\
\text { always }\end{array}$ & usually & sometimes & almost never & & \\
\hline Gender & Male & 7 & 11 & 19 & 3 & 2.55 & .87 \\
\hline & & $8.8 \%$ & $13.8 \%$ & $23.8 \%$ & $3.8 \%$ & & \\
\hline & Female & 1 & 7 & 24 & 8 & 2.02 & .69 \\
\hline & & $1.3 \%$ & $8.8 \%$ & $30.0 \%$ & $10.0 \%$ & & \\
\hline
\end{tabular}

In terms of language learning motivation, it can be inferred from the results in Table 5 that males and females differ in this aspect.

Table 5. Directional Measures between genders in language learning motivation

\begin{tabular}{llll}
\hline & & Value \\
\hline Nominal by Interval & Eta & gender dependent & .52 \\
& & Gender differences in .11 \\
& English language learning \\
& motivation Dependent \\
\hline
\end{tabular}

Male and female motivation can be attributed to their attitude toward English learning as the results in Table 6 show that there is a strong correlation between the two statements which are: "I enjoy learning English" and "I feel strongly motivated to learn English.

Table 6. Correlations between motivation and attitude

\begin{tabular}{llll}
\hline & & $\begin{array}{l}\text { I enjoy } \\
\text { learning } \\
\text { English. }\end{array}$ & $\begin{array}{l}\text { I feel strongly } \\
\text { motivated to } \\
\text { learn English. }\end{array}$ \\
\hline I enjoy learning English. & $\begin{array}{l}\text { Pearson Correlation } \\
\text { Sig. (2-tailed) }\end{array}$ & 1 & $.66^{* *}$ \\
& $\mathrm{~N}$ & 80 & .00 \\
& & 80 \\
\hline $\begin{array}{l}\text { I feel strongly motivated to Pearson Correlation } \\
\text { learn English. }\end{array}$ & $.66^{* *}$ & 1 \\
& $\mathrm{~N}$ & .00 & \\
& $\mathrm{~N}$ & 80 & 80 \\
\hline
\end{tabular}

**. Correlation is significant at the 0.01 level (2-tailed).

The results indicate that males and females are not equal in terms of language learning motivation as only 20 males out of 40 responded that they always feel motivated to learn English while 29 females out of 40 have respond that that they have always felt so. Because learner motivation is strongly correlated to self-efficacy as can be inferred from Table 7, it is unsurprising that females have high self-efficacy compared with males. The responses to Statement 3, in which the female mean is 3.42 while male mean is 3.12, support this correlation. 
International Journal of Applied Linguistics \& English Literature

ISSN 2200-3592 (Print), ISSN 2200-3452 (Online)

Vol. 1 No. 4; September 2012

Table 7. Correlations between learner motivation and self-efficacy

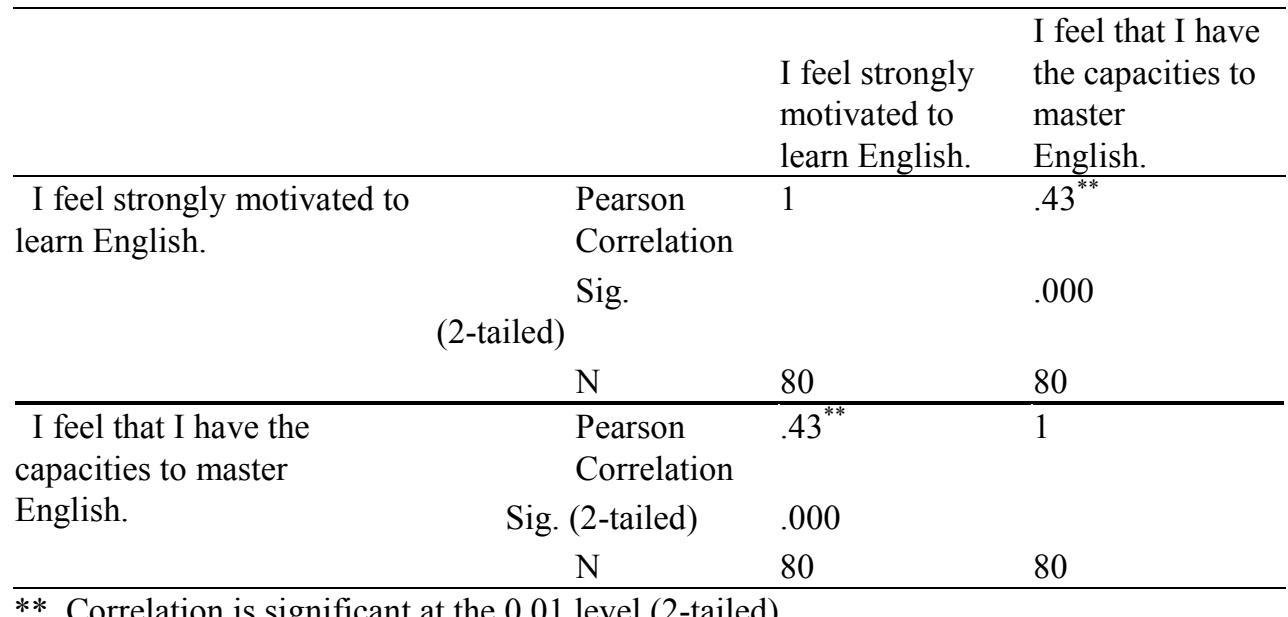

**. Correlation is significant at the 0.01 level (2-tailed).

These differences between males and females in language learning attitudes can be attributed to male interest as they seem to be more interested in science-oriented subjects, as can be seen from the result of Statement 5 in Table $4(\mathrm{M}=2.55)$ than in art-oriented subjects and learning English focuses more on literature and art-oriented passages.

Chan, Spratt and Gillian (2010) have explained that language learners tend to improve their skills using numerous strategies and, more importantly, that they work on their language autonomously when they have high self-efficacy. However, the results are in contrast with the previous view as males feel that they are personally responsible of developing their language $(M=3.62)$ and they said that they work on their language using different activities outside the classroom in addition to classroom activities $(\mathrm{M}=2.97)$ more than females as the female means in the two previous statements are $(M=3.57)$ and $(M=2.77)$ respectively. This is the result when males have lower self-efficacy than females.

Table 8. Gender differences in language learning motivation

\begin{tabular}{|c|c|c|c|c|c|c|c|}
\hline & \multicolumn{4}{|c|}{ 1- I enjoy learning English. } & \multirow[t]{2}{*}{$\mathrm{M}$} & \multirow[t]{2}{*}{ SD } \\
\hline & & $\begin{array}{l}\text { almost } \\
\text { always }\end{array}$ & usually & Sometimes & almost never & & \\
\hline \multirow[t]{4}{*}{ Gender } & \multirow[t]{2}{*}{ Male } & 22 & 15 & 1 & 2 & \multirow[t]{2}{*}{3.42} & \multirow[t]{2}{*}{.78} \\
\hline & & $27.5 \%$ & $18.8 \%$ & $1.3 \%$ & $2.5 \%$ & & \\
\hline & \multirow[t]{2}{*}{ Female } & 31 & 8 & 1 & 0 & \multirow[t]{2}{*}{3.75} & \multirow[t]{2}{*}{.49} \\
\hline & & $38.8 \%$ & $10.0 \%$ & $1.3 \%$ & $.0 \%$ & & \\
\hline & & \multicolumn{4}{|c|}{ 2- I feel strongly motivated to learn English. } & \multirow[t]{2}{*}{ M } & \multirow[t]{2}{*}{$\mathrm{SD}$} \\
\hline & & $\begin{array}{l}\text { almost } \\
\text { always }\end{array}$ & usually & Sometimes & almost never & & \\
\hline \multirow[t]{4}{*}{ Gender } & \multirow[t]{2}{*}{ Male } & 20 & 16 & 4 & 0 & \multirow[t]{2}{*}{3.40} & \multirow[t]{2}{*}{.67} \\
\hline & & $25.0 \%$ & $20.0 \%$ & $5.0 \%$ & $.0 \%$ & & \\
\hline & \multirow[t]{2}{*}{ Female } & 29 & 9 & 0 & 2 & \multirow[t]{2}{*}{3.62} & \multirow[t]{2}{*}{.74} \\
\hline & & $36.3 \%$ & $11.3 \%$ & $.0 \%$ & $2.5 \%$ & & \\
\hline & & \multicolumn{4}{|c|}{ 3- I feel that I have the capacities to master English. } & \multirow[t]{2}{*}{ M } & \multirow[t]{2}{*}{ SD } \\
\hline & & $\begin{array}{l}\text { almost } \\
\text { always }\end{array}$ & usually & Sometimes & almost never & & \\
\hline \multirow[t]{4}{*}{ Gender } & Male & 17 & 14 & 6 & 3 & \multirow[t]{2}{*}{3.12} & \multirow[t]{2}{*}{.94} \\
\hline & & $21.3 \%$ & $17.5 \%$ & $7.5 \%$ & $3.8 \%$ & & \\
\hline & \multirow[t]{2}{*}{ Female } & 25 & 8 & 6 & 1 & \multirow[t]{2}{*}{3.42} & \multirow[t]{2}{*}{.844} \\
\hline & & $31.3 \%$ & $10.0 \%$ & $7.5 \%$ & $1.3 \%$ & & \\
\hline & & \multicolumn{4}{|c|}{ 4- I have the passion to learn and develop my English. } & M & SD \\
\hline
\end{tabular}

Page | 239

This paper is licensed under a Creative Commons Attribution 3.0 License. 
International Journal of Applied Linguistics \& English Literature

ISSN 2200-3592 (Print), ISSN 2200-3452 (Online)

Vol. 1 No. 4; September 2012

\begin{tabular}{|c|c|c|c|c|c|c|c|}
\hline & & $\begin{array}{l}\text { almost } \\
\text { always }\end{array}$ & usually & Sometimes & almost never & & \\
\hline Gender & Male & 17 & 17 & 6 & 0 & 3.27 & .716 \\
\hline & & $21.3 \%$ & $21.3 \%$ & $7.5 \%$ & $.0 \%$ & & \\
\hline & Female & 33 & 6 & 0 & 1 & 3.77 & .58 \\
\hline & & $41.3 \%$ & $7.5 \%$ & $.0 \%$ & $1.3 \%$ & & \\
\hline & & 5- I ha & gh self-e & $\mathrm{n}$ in learning & glish. & $\mathrm{M}$ & SD \\
\hline & & $\begin{array}{l}\text { almost } \\
\text { always }\end{array}$ & usually & Sometimes & almost never & & \\
\hline Gender & Male & 20 & 17 & 2 & 1 & 3.40 & .71 \\
\hline & & $25.0 \%$ & $21.3 \%$ & $2.5 \%$ & $1.3 \%$ & & \\
\hline & Female & 24 & 12 & 2 & 2 & 3.45 & .81 \\
\hline & & $30.0 \%$ & $15.0 \%$ & $2.5 \%$ & $2.5 \%$ & & \\
\hline & & $\begin{array}{c}\text { 6- I } \\
\text { develop }\end{array}$ & $\begin{array}{l}\text { that } \mathrm{I} \\
\text { ny langu: }\end{array}$ & the person & sponsible for & $\mathrm{M}$ & SD \\
\hline & & $\begin{array}{l}\text { almost } \\
\text { always }\end{array}$ & usually & Sometimes & almost never & & \\
\hline Gender & Male & 25 & 15 & 0 & 0 & 3.62 & .49 \\
\hline & & $31.3 \%$ & $18.8 \%$ & $.0 \%$ & $.0 \%$ & & \\
\hline & Female & 28 & 9 & 1 & 2 & 3.57 & .78 \\
\hline & & $35.0 \%$ & $11.3 \%$ & $1.3 \%$ & $2.5 \%$ & & \\
\hline & & $\begin{array}{r}7-\mathrm{I} \mathrm{d} \\
\text { and acti }\end{array}$ & $\begin{array}{l}\text { merely } \\
\text { to impr }\end{array}$ & $\begin{array}{l}\text { ny English to } \\
\text { ny language. }\end{array}$ & hers' teaching & $\mathrm{M}$ & SD \\
\hline & & $\begin{array}{l}\text { almost } \\
\text { always }\end{array}$ & usually & Sometimes & almost never & & \\
\hline Gender & Male & 4 & 12 & 15 & 9 & 2.27 & .93 \\
\hline & & $5.0 \%$ & $15.0 \%$ & $18.8 \%$ & $11.3 \%$ & & \\
\hline & Female & 8 & 7 & 18 & 7 & 2.40 & 1.01 \\
\hline & & $10.0 \%$ & $8.8 \%$ & $22.5 \%$ & $8.8 \%$ & & \\
\hline & & $\begin{array}{r}8 \text { - I n } \\
\text { outside } \\
\text { activitie }\end{array}$ & $\begin{array}{r}\text { on my } 1 \\
\text { classro }\end{array}$ & $\begin{array}{l}\text { age using di } \\
\text { in addition }\end{array}$ & $\begin{array}{l}\text { rent activities } \\
\text { to classroom }\end{array}$ & $\mathrm{M}$ & SD \\
\hline & & $\begin{array}{l}\text { almost } \\
\text { always }\end{array}$ & usually & Sometimes & almost never & & \\
\hline Gender & Male & 11 & 17 & 12 & 0 & 2.97 & .77 \\
\hline & & $13.8 \%$ & $21.3 \%$ & $15.0 \%$ & $.0 \%$ & & \\
\hline & Female & 9 & 17 & 10 & 4 & 2.77 & .92 \\
\hline & & $11.3 \%$ & $21.3 \%$ & $12.5 \%$ & $5.0 \%$ & & \\
\hline
\end{tabular}

Student responses to the question in the open-ended section indicate that the majority of them, 70 participants out of 80 , believe that society and culture play no noticeable role in gender differences in English learning. They believe that nowadays society provides equal opportunities for both males and females as there are various ways to learn English, such as watching TV and reading English books. Some indicate that learning English opportunities have expanded even more now that the internet exists, since it makes the whole world a village and people can interact with each other in their homes. However, 10 participants out of 40 have contrary views. 8 participants, 6 females and 2 males, responded that Omani males have many advantages in learning English as they are allowed to travel abroad and meet foreign people, unlike females who are expected or encouraged to stay at home most of the time. Because "learning any language can be achieved through interaction with native speakers," as one participant indicated, and as Omani males have the chance to interact with native speakers more than Omani females, their language may develop more. On the other hand two male participants suggested that Omani females have more opportunity to learn English as they are just sitting at home, so they can watch English programs or read in English more than males, who spend a lot of time outside their homes. Such difference in views among participants is not surprising as their views might vary according to the place where 
they live or their living situation, for example on or off campus. For example, people who live in big cities tend to take the first view, which is that society and culture have no role in gender differences in English language learning.

\section{Results}

This study has examined the influence of gender on English language learning among Sultan Qaboos University. It sought answers to the following questions:

\section{What are the gender differences in language learning strategies?}

Based on the results found regarding students' attitudes toward language learning strategies and the types and numbers of such strategies they use, noticeable differences between males and females exist. The results imply that males and females not only differ in terms of the numbers of language learning strategies they utilize, but also in terms of strategy variation. It was found that females exercise more numerous and varied types of language learning strategies, especially memory and social strategies, when compared with males. These findings correspond with Liyanage's and Bartlett's (2011) view that females use more strategies compared with males and with Ran's and Oxford's (as cited in Studenska, 2011, p.1351) that females use memory, cognitive, compensation, metacognitive and social strategies more frequently than males. However, the results contradicted Ran's and Oxford's view (as cited in Studenska, 2011) on one point which is related to cognitive strategies, as the results imply that females do not always compete with males in using cognitive strategies. But the conclusion, that either males are superior to females in using such strategies or vice versa, might vary depending on the nature of the cognitive exercise itself. Besides, the results indicate that gender differences in language learning strategies occur primarily because of the learners' attitude. Hence, females tend to use such strategies more than males because they strongly believe that using learning strategies contributes to their language performance development. Consequently, the results provide useful insights into how teachers can increase the frequency of using language learning strategies among students whether they are males or females. That is, they have to encourage students to use them and convince them that using such strategies is really needed for the development of their performance.

\section{What are gender differences on language comprehension?}

According to the results, female and male differences in language comprehension depend on the type of texts that they deal with, even though the results indicate that somehow females are better than males in general language understanding. Males show better comprehension than females of science-oriented passages and in passages that are full of aggressiveness and fighting, while females can deal with art-oriented passages and the passages that have emotional and sensitive language better than males. These results are consistent with many research findings, including Brantmeier's (2003), Pea's (2004) and Glenberg's (2009). Based on these results, caution is required when teachers select any passages for their students.

\section{What are the gender differences in language learning motivation?}

Psychologically speaking, language learning motivation is affected by learners' attitudes. According to the results, males and females do not have the same enthusiasm in learning English. Females are more enthusiastic than males. Hence, the finding that indicates that females are more motivated than males to learn English is reasonable. As learner motivation to learn English affects self-efficacy, females have more self-efficacy than males have.

According to Chan, Spratt and Gillian (2010), language learners who have high self-efficacy tend to improve their language autonomously more than other learners. However, the results of the current study went against the previous view, as they show that males who, as the study shows, have lower self-efficacy than female tend to develop their language by practicing more activities than females outside the classroom.

\section{What are the roles of society and culture in gender differences?}

As previously discussed in the results, the study found that there is no noticeable role for society and culture in gender differences in English language learning in Oman, especially nowadays. Males and females have equal an opportunity to learn English in Omani society as most of the barriers that prevented women from studying English, for example travelling abroad, have been removed. Moreover, there are various ways available for both males and females to improve their language such as watching English programs and reading English books, newspapers and magazines. 


\section{Conclusion}

To our knowledge, this study is the first to investigate gender differences in English language learning among Sultan Qaboos University students. The researchers found that differences in English learning at the University do exist in regard to language learning strategies, language comprehension and language learning motivation. In addition, participants' opinion indicated that Omani society provides equal opportunities to learn English for both males and females.

Because the current study focused only on students from four colleges, it is recommended that further research should be carried out on SQU's other colleges in order to check whether the findings can be generalized. However, the present findings might be useful in developing English education in Oman if teachers take into consideration the differences between males and females and try to teach English in a way that is appropriate for each gender. Teachers also should be trained to select suitable reading or listening texts as they do not have to merely consider the level of their students but also their students' emotional reaction and their interest in certain types of content.

Some of the causes of the differences between males and females in language learning are not preventable, especially those related to the role of society and culture. As a result, co-education might not be advisable in language classes due to gender differences.

\section{References}

Al-Mahrooqi, R. \& Sultana, T. (forthcoming). "Unheard Melodies"' from behind the veil: Male and female Oman student responses to translated short stories by Arab women writers. English Language Teaching World Online (ELTwo).

Andreou, G., Vlachos, F., \& Andreou, E. (2005). Affecting factors in second language learning. Journal of Psycholinguistic Research, 34, 429-438. doi: 10.1007/s10936-005-6202-0.

Aslan, O. (2009). The role of gender and language learning strategies in learning English (Master dissertation). Available from http:// etd.lib.metu.edu.tr/upload/ 12611098/index.pdf.

Bacon, S. M. (1992). The relationship between gender, comprehension, processing strategies, and cognitive and affective response in foreign language listening. The Modern Language Journal, 76, 160-178. Retrieved from http://www.jstor.org/stable/329769 on March 1, 2012.

Brantmeier, C. (2003). Does gender make a difference? Passage content and comprehension in second language reading. Reading in a Foreign Language, 15. Retrieved from http://www.nflrc.hawaii.edu/rfl/April2003/brantmeier.html on April 52012.

Catalan, R. M. J. (2003). Sex differences in L2 vocabulary learning strategies. International Journal of Applied Linguistics, 13, 54-77. doi: 10.1111/1473-4192.00037.

Chan, V., Spratt, M., \& Humphreys, G. (2010). Autonomous language learning: Hong Kong tertiary students' attitudes and behaviours. Evaluation and Research in Education, 16, 1-18. Ido: 10.1080/09500790208667003.

Choi, N. (2004). Sex role grouping differences in specific, Academic, and general self-efficacy. The Journal of Psychology, 138, 149-159. Retrieve from

Glengerg, A. M., Webster, B. J., Mouilso, E., Havas, D., \& Lindema, L. M. (2009). Gender, emotion, and the embodiment of language comprehension. The International Society for Research on Emotion, 1, 151-161. Ido: 10.1177/1754073908100440.

Kaiser, S. A. (2006). Gender differences in learning: Teachers' awareness and instructional practices (Master dissertation). Available from ProQuest Dissertation and theses database. (UMI 1434048).

Liyanage, I., \& Bartlett, B. J. (2001). Gender and language learning strategies: Looking beyond the categories. The Language learning Journal, 1-17. doi: 10.1080/09571736.2011.574818.

Magogwe, J. M., \& Oliver, R. (2007). The relationship between language learning strategies, proficiency, age and self-efficacy beliefs: A study of language learners in Botswana. System, 35, 338-352. Doi:

10.1016/j.system.2007.01.003.

Meece, J. L. , Glienke, B. B, \& Burg, S. (2006). Gender and motivation. Journal of School Psychology, 44, 351-373. Ido: 10.1016/j.jsp.2006.04.004. 
International Journal of Applied Linguistics \& English Literature

ISSN 2200-3592 (Print), ISSN 2200-3452 (Online)

Vol. 1 No. 4; September 2012

Mori, S., Gobel, P. (2006). Motivation and gender in the Japanese EFL classroom. System, 34, 194-210. Doi: 10.1016/j.system. 2005.11.002.

Ning, H., (2010). On gender difference in English language and its causes. Asian Social Science, 6, 126-130. Retrieved from http:www.ccsenet.org/ass.

Payne, T. W. , \& Lynn, R. (2011). Sex differences in second language comprehension. Personality and Individual Differences, 50, 434-436. Retrieved from http:// dx.doi.org/10.1016/j.paid.2010.10.026.

Pae, T. (2004). Gender effect on reading comprehension with Korean EFL learners. System, 32, 265-281. Doi:10.1016/j.system.2003.09.009.

Samida, D. K. (2004). Language learning strategies. Retrieved from http://libro.do-bunkyodai.ac.jp/research/pdf/treatises05/01Samidaa.pdf on April 5, 2012.

Studenska, A. (2011). Educational level, gender and foreign language learning self-regulation difficulty. Procedia - Social and Behavioral Sciences, 29, 1349-1358. doi: 10.1016/j.sbspro.2011. 11.373.

Varol, B. \& Yilmaz, S. (2010). Similarities and differences between female and male learners: Inside and outside class autonomous language learning activities. Procedia Social and Behavioral Science, 3, 237-244. ido: 10.1016/j.sbspro.2010.07.038

Wong, L. L. C., \& Nunan, D. (2011). The learning styles and strategies of effective language learners. System, 39, 144-163. Doi: 10.1016/j.system.2011.05.004.

Yilmaz, C. (2010). The relationship between language learning strategies, gender, proficiency and self-efficacy beliefs: a study of ELT learners in Turkey. Procedia Social and Behavioral Sciences, 2, 682-687. Doi: 10.1016/j.sbspro.2010.03.084.

Ylviskaker, M. (2008, April). What is language comprehension? Retrieved from http://www.project;earnet.org/tutorials/language comprehension.html on March 1, 2012.

Yusuf, M. (2011). Investigating relationship between self-efficacy, achievement motivation and self-regulated learning strategies of undergraduate students: A study of integrated motivational models. Procedia Social and Behavioral Sciences, 15, 2614-2617. doi: 10.1016/j.sbspro.2011.04.156

\section{Appendix}

A questionnaire on the Influence of Gender on English Language Learning

\section{Among College Students in Oman}

This study aims to investigate whether gender has any influence on English language leaning among college students in Oman. I will be grateful to you if you answered the following questions sincerely. Be assured that your answers will remain confidential and will only be used for research purposes. Thank you in advance.

Background Information:

Gender

College where you study

Major

Year at college

A: For every item, please tick under the column that best describes your response:
1 Almost Always
[76-100\% of the time]
2 Usually
[51-75\% of the time]
3 Sometimes
[26-50\% of the time]
4 Almost Never
[0-25\% of the time]

Page $\mid 243$ 


\section{International Journal of Applied Linguistics \& English Literature \\ ISSN 2200-3592 (Print), ISSN 2200-3452 (Online)}

Vol. 1 No. 4; September 2012

1. Gender differences in language learning strategies:

\begin{tabular}{|c|c|c|c|c|c|}
\hline NO. & The statements & $\begin{array}{l}\text { Almost } \\
\text { Always }\end{array}$ & Usually & sometimes & $\begin{array}{l}\text { Almost } \\
\text { never }\end{array}$ \\
\hline 1. & $\begin{array}{l}\text { I use various types of language learning strategies to learn } \\
\text { English. }\end{array}$ & & & & \\
\hline 2. & I do not focus on one strategy to develop my language. & & & & \\
\hline 3. & I group words in order to memorize them. & & & & \\
\hline 4. & I repeat words many times to learn them. & & & & \\
\hline 5. & I tend to analyze what I read/hear in English. & & & & \\
\hline 6. & $\begin{array}{l}\text { I tend to summarize what I hear/read in English using my own } \\
\text { words. }\end{array}$ & & & & \\
\hline 7. & $\begin{array}{l}\text { I like communicating with native speakers to develop my } \\
\text { English. }\end{array}$ & & & & \\
\hline 8. & $\begin{array}{l}\text { My language develops more when I use various types of } \\
\text { language learning strategies. }\end{array}$ & & & & \\
\hline 9. & $\begin{array}{l}\text { I understand what I learn more when I use language learning } \\
\text { strategies. }\end{array}$ & & & & \\
\hline 10. & $\begin{array}{l}\text { There is no difference in my performance whether I use one or } \\
\text { many types of language learning strategies. }\end{array}$ & & & & \\
\hline
\end{tabular}

2. Gender differences in English language comprehension

\begin{tabular}{|c|c|c|c|c|c|}
\hline NO. & The statements & $\begin{array}{l}\text { Almost } \\
\text { always }\end{array}$ & Usually & Sometimes & $\begin{array}{l}\text { Almost } \\
\text { Never }\end{array}$ \\
\hline 1. & I hardly understand what others say or write in English. & & & & \\
\hline 2. & $\begin{array}{l}\text { I interact more with English texts that are full of sensitive and } \\
\text { emotional feelings. }\end{array}$ & & & & \\
\hline 3. & I interact more with English texts that contain action and fighting. & & & & \\
\hline 4. & I understand more art-oriented English passages. & & & & \\
\hline 5. & I understand more science-oriented English passages. & & & & \\
\hline
\end{tabular}

3. Gender differences in English language learning motivation:

\begin{tabular}{|c|c|c|c|c|c|}
\hline NO. & The statements & always & sometime & rarely & Never \\
\hline 1. & I enjoy learning English. & & & & \\
\hline 2. & I feel strongly motivated to learn English. & & & & \\
\hline 3. & I feel that I have the capacity to master English. & & & & \\
\hline 4. & I have the passion to learn and develop my English. & & & & \\
\hline 5. & I have high self-esteem in learning English. & & & & \\
\hline 6. & I feel that I am the person responsible for developing my language. & & & & \\
\hline 7. & $\begin{array}{l}\text { I depend merely on my English teachers' teaching and activities to } \\
\text { improve my language. }\end{array}$ & & & & \\
\hline 8. & $\begin{array}{l}\text { I work on my language using different activities outside the classroom } \\
\text { in addition to classroom activities. }\end{array}$ & & & & \\
\hline 9. & I like watching English movies and listening to English songs. & & & & \\
\hline 10. & I write a lot in English (e.g., my diaries, stories, articles). & & & & \\
\hline 11. & $\begin{array}{l}\text { I like reading in English (e.g., magazines, newspapers, short stores, } \\
\text { novels). }\end{array}$ & & & & \\
\hline 12. & $\begin{array}{l}\text { I like speaking in English (e.g., with my peers, with native speakers, } \\
\text { with my siblings). }\end{array}$ & & & & \\
\hline
\end{tabular}

B: What roles do society and culture play in determining gender differences in English language learning?

Thank you for your cooperation. 